\section{POS0331 LUNG TARGETED DELIVERY OF EVEROLIMUS AS A NEW TREATMENT OF SCLERODERMA-RELATED INTERSTITIAL LUNG DISEASE (SSC-ILD) DEVELOPED BY PSGL-1 KO MICE}

E. González Sánchez ${ }^{1}$, J. Gómez-Román², A. Muñoz-Callejas ${ }^{3}$, A. Marengo ${ }^{4}$, N. Tsapis ${ }^{4}$, K. Bohne-Japiassu ${ }^{4}$, M. Á. González-Gay ${ }^{5}$, E. F. VicenteRabaneda $^{3}$, E. Fattal ${ }^{4}$, S. Castañeda ${ }^{3}$, A. Urzainqui ${ }^{1} .{ }^{1}$ Fundación de Investigación Biomédica, Instituto de Investigación Sanitaria-Princesa, Hospital de La Princesa, Servicio de Inmunología, Madrid, Spain; ${ }^{2}$ Universidad de Cantabria. Hospital Universitario Marqués de Valdecilla, IDIVAL, Servicio de Anatomía Patológica, Santander, Spain; ${ }^{3}$ Fundación de Investigación Biomédica, Instituto de Investigación Sanitaria-Princesa, Hospital de La Princesa, Servicio de Reumatología, Madrid, Spain; ${ }^{4}$ Institut Galien Paris Sud, School of Pharmacy at University Paris-Saclay, Paris, France; ${ }^{5}$ Universidad de Cantabria. Hospital Universitario Marqués de Valdecilla, IDIVAL, Servicio de Reumatología, Santander, Spain

Background: Interstitial lung disease (ILD), the main cause of mortality in scleroderma (SSc) patients (1), has no treatment (2). P-selectin glycoprotein ligand 1 (PSGL-1), the main ligand for P-Selectin, is expressed on leukocytes and responsible for the initial steps of extravasation (3). The absence of PSGL-1 in mice spontaneously develops an autoimmune syndrome similar to human SSc with fibrosis, vascular damage, autoantibodies and pulmonary arterial hypertension in females, and almost $60 \%$ of animals older than 12 months develop ILD with aging (4). In this work, the therapeutic action of everolimus-loaded nanomedicine given by local administration as a treatment for ILD was evaluated. The intratracheal administration of everolimus loaded into in liposomes decorated with hyaluronic acid $(\mathrm{HA})$ is studied as an administration strategy to reach the inflammatory and fibrotic cells, targeting these cells and avoiding systemic effects and possible toxicity on epithelial cells

Objectives: 1) To study the effect of everolimus on bronchoalveolar lavage (BAL) cell populations and in lung pathology in SSc-ILD PSGL-1 KO mice

2) To analyze the intratracheal application of everolimus included in empty liposomes (Lip+Ev) vs. liposomes decorated with hyaluronic acid (Lip-HA+Ev) as an administration strategy to decrease drug toxicity and increase drug effectivity Methods: In an observational study, PSGL-1 $1^{-1-}$ C57BL/6 males older than 12 months $(n=4)$ were treated intratracheally with 4 doses of Lip or Lip-HA (with or without everolimus included), once a week (Lip+Ev 295.67 $\mu \mathrm{g} / \mathrm{mL}$; Lip+Ev $82.73 \mu \mathrm{g} / \mathrm{mL}$; Lip-HA+Ev $82.73 \mu \mathrm{g} / \mathrm{mL}$ ). Then, animals were euthanatized and BAL and lungs were obtained. BAL cells were stained for flow cytometry analysis. Lungs were embedded in paraffin blocks for blind histological analysis by a pathologist and evaluated for interstitial inflammation and fibrosis degree. Lip-HA was selected as the treatment of choice for a second experiment $(n=8)$ following the same experimental design $(86.22 \mu \mathrm{g} / \mathrm{mL})$

Results: The observational study showed an increase in $\mathrm{CD}_{4} 5^{+}$, alveolar macrophages (AM), eosinophils (Eos), granulocytes $\left(\mathrm{Gr}^{+}\right)$and $\mathrm{T}$ cells in the BAL of untreated PSGL-1/- mice compared with WT mice. Everolimus reduced these populations to WT levels in all cases

Lip-HA+Ev administration was chosen for further experiments because a lower dose of the drug gave a better result than the high dose in undecorated liposomes. Reduction of $\mathrm{CD} 45^{+}$, AM, eosinophils, and $\mathrm{CD} 45^{\circ}$ cells populations by Lip$\mathrm{HA}+\mathrm{Ev}$ was confirmed. Lip-HA treatment increased the number of neutrophils and $T$ cells, but this effect is controlled by the everolimus administration

Histological lung analysis showed an increase in interstitial inflammation and fibrosis in untreated PSGL-1/ and empty Lip-HA experimental groups. Treatment with everolimus included in Lip-HA reduced the fibrotic and inflammatory interstitial lung lesions, reaching values similar to those observed in WT mice

Conclusion: PSGL-1 KO mice present ILD associated with scleroderma (SScILD) with an increase of $\mathrm{CD}_{4} 5^{+}, \mathrm{Gr}^{+}$, Eos, $\mathrm{T}$ cells and AM populations in the BAL. Intratracheal treatment with everolimus included in liposomes decorated with hyaluronic acid reduces immune cell infiltration and fibrosis once SSc-ILD is established

REFERENCES:

[1] Solomon JJ, Olson AL, Fischer A, Bull T, Brown KK, Raghu G (2013). Scleroderma lung disease

[2] Singh D, Parihar AK, Patel S, Srivastava S, Diwan P, Singh MR (2019). Scleroderma: An insight into causes, pathogenesis and treatment strategies. Pathophysiology, 26(2)

[3] Zarbock A, McEver RP, Hidalgo A (2011). Leukocyte Ligands for Endothelial Selectins: Specialized Glycoconjugates That Mediate Rolling and Signaling Under Flow. BLOOD

[4] Pérez-Frías A, Núñez-Andrade N, et al. (2014). Development of an autoimmune syndrome affecting the skin and internal organs in P-selectin glycoprotein ligand 1 leukocyte receptor-deficient mice. Arthritis Rheumatol

Disclosure of Interests: None declared

DOI: 10.1136/annrheumdis-2021-eular.2498

\section{POS0332 ENDOTHELIAL ACTIVATION IN SYSTEMIC SCLEROSIS VASCULOPATHY: ROLE OF LONG NON-CODING RNA H19X}

F. Tirelli ${ }^{1}, 2$, E. Pachera ${ }^{1}$, R. Lafyatis ${ }^{3}$, M. Huang ${ }^{2}$, F. Zulian², G. Kania ${ }^{1}$, O. Distler ${ }^{1}{ }^{1}$ Department of Rheumatology, Center of Experimental Rheumatology, University Hospital Zurich, University of Zurich, Zurich, Switzerland; ${ }^{2}$ Rheumatology Unit, Department of Woman's and Child's Health, University of Padova, Padova, Italy; ${ }^{3}$ Division of Rheumatology and Clinical Immunology, Department of Medicine, University of Pittsburgh, Pittsburgh, Pennsylvania, United States of America

Background: Long non-coding RNAs (IncRNA) are a class of non-coding transcripts which modulate many biological processes. Our previous studies showed that IncRNA H19X is pivotal in the regulation of TGF $\beta$ driven fibrosis in systemic sclerosis (SSc) ${ }^{1}$.

Objectives: We aimed to investigate whether H19X plays a functional role in the regulation of endothelial cell (EC) activation, which is crucial in SSc vasculopathy ${ }^{2}$. Methods: Single-cell RNA sequencing (scRNA-seq) data from 27 dcSSc and 10 healthy control $(\mathrm{HC})$ skin biopsies, following $10 \mathrm{X}$ Genomics partitioning and CDNA preparation, were analyzed for $\mathrm{H} 19 \mathrm{X}$ expression in skin ECs, using Seurat package in $\mathrm{R}$. A total of $4,981 \mathrm{ECs}$, of which 1,583 cells originated from $\mathrm{HC}$ and 3,398 cells originated from SSc patients, ranging from 59 to 342 ECs per subject, characterized by enrichment of EC markers of CLDN5, VWF and PECAM1.

Expression of H19X in Human Dermal Microvascular ECs (HDMEC) was analyzed by QPCR. HDMEC were stimulated with different proinflammatory cytokines including IFN $\alpha$, IFN $\beta$, IFN $\gamma$, TGF $\beta$, TNF $\alpha$, IL-6, IL-1 $\beta$ and IL-4 at biologically relevant concentrations. In order to ascertain its effect in ECs, H19X was silenced in HDMECs using locked nucleic acid antisense oligonucleotides (LNA GapmeRs). qPCR and Western Blot (WB) were used to analyze the effects of H19X downregulation on $\mathrm{EC}$ activation biomarkers.

Results: scRNA-seq data showed that H19X was significantly upregulated in SSc compared to healthy ECs $(p=0.0095)$. Based on the differentially expressed gene profiles among subclusters, EC were further annotated as arterial (SEMA3G, HEY1), capillary (CA4, RGCC), venous (ACKR1, VCAM1), lymphatic (PROX1, LYVE1) ECs, as well as two aberrant clusters, proliferating (TOP2A, MKI67) and injured (HSGP2, APLNR) ECs, which were dominated by the SSc ECs. Specifically, the highest expression of $\mathrm{H} 19 \mathrm{X}$ was found in injured SSc ECs and capillary SSc ECs. Overall, $1.5 \%$ SSc EC, about 51 cells, expressed detectable levels of $\mathrm{H} 19 \mathrm{X}$. In HDMEC $(\mathrm{n}=3), \mathrm{H} 19 \mathrm{X}$ was consistently induced by IFN $\alpha$, IFN $\beta$ and IFN $\gamma$. Time curve analysis demonstrated that the strongest induction was observed at $48 \mathrm{H}$ $(1.5 \pm 0.2,1.6 \pm 0.4$ and $2.1 \pm 0.3-$ fold increase respectively). The combination of different IFNs determined stronger $\mathrm{H} 19 \mathrm{X}$ induction after $48 \mathrm{H}$ stimulation, with a $2.4 \pm 0.1$ increase with the combination of all IFNs and a $2.4 \pm 0.1$ increase after the combination of IFN $\alpha+\gamma$.

Importantly, H19X knockdown lead to consistent and significant decrease of mRNAs of several adhesion molecules, including VCAM1, E- Selectin and P-Selectin, both in untreated HDMEC and after IFN stimulation. A decrease of VCAM and P-Selectin could be also demonstrated with WB analysis. No change was seen in other EC activation markers, including endothelin-1 and angiogenesis markers including VEGF, VEGFRA, Tie2 and thrombospondin.

Conclusion: This is the first report analyzing a potential role of IncRNA H19X in SSc vasculopathy. Our results suggest that IncRNA H19X could act as a regulator of adhesion molecules expression in EC, possibly mediated by IFNs, and be therefore involved in EC activation.

\section{REFERENCES:}

[1] Pachera $\mathrm{E}$, et al. Long noncoding RNA H19X is a key mediator of TGF- $\beta$ driven fibrosis. J Clin Invest. 2020 Sep 1;130(9):4888-4905.

[2] Mostmans Y, et al. The role of endothelial cells in the vasculopathy of systemic sclerosis: A systematic review. Autoimmun Rev. 2017 Aug;16(8):774-786.

Acknowledgements: I have no acknowledgements to declare

Disclosure of Interests: Francesca Tirelli: None declared, Elena Pachera: None declared, Robert Lafyatis Consultant of: RL served as a consultant with Bristol Meyers Squibb, Formation, Sanofi, Boehringer-Ingelheim, Merck, and Genentech/ Roche, Acceleron, Grant/research support from: RL received grants form Bristol Meyer Squib, Corbus, Formation, Moderna, Regeneron, Pfizer, and Kiniksa, Menqi Huang: None declared, Francesco Zulian: None declared, Gabriela Kania: None declared, Oliver Distler Speakers bureau: Speaker fee on Scleroderma and related complications and on other rheumatology topics: Actelion, Bayer Boehringer Ingelheim, Medscape, Novartis, Roche, Menarini, Mepha, MSD, iQone, Pfizer, Consultant of: Has consultancy relationship in the area of potential treatments for systemic sclerosis and its complications (last three years):Abbvie, Actelion, Acceleron Pharma, Amgen, AnaMar, Arxx Therapeutics, Bayer, Baecon Discovery, Blade Therapeutics, Boehringer, CSL Behring, ChemomAb, Corpuspharma, Curzion Pharmaceuticals, Ergonex, Galapagos NV, GSK, Glenmark Pharmaceuticals, Inventiva, Italfarmaco, iQvia, -Kymera, Medac, Medscape, Mitsubishi Tanabe Pharma, MSD, Roche, Sanofi, UCB, Lilly, Target BioScience, Pfizer. Consultancy relationship for rheumatology topic other than Scleroderma: 
Abbvie, Amgen, Lilly, Target BioScience, Pfizer. In addition, he holds a patent issued "mir-29 for the treatment of systemic sclerosis" (US8247389, EP2331143)., Grant/research support from: Has received grants/research support in the are of potential treatments for systemic sclerosis from Actelion, Bayer, Boehringer Ingelheim, Kymera Therapeutics, Mitsubishi Tanabe Pharma DOI: 10.1136/annrheumdis-2021-eular.3028

\section{POS0333 ALTERED MACROPHAGE POLARIZATION PHENOTYPES IN SYSTEMIC SCLEROSIS}

A. Hukara ${ }^{1}$, M. Rudnik ${ }^{1}$, C. B. Rufer ${ }^{1}$, O. Distler ${ }^{1}$, P. Blyszczuk ${ }^{1}$, G. Kania ${ }^{1}$ ${ }^{1}$ University Hospital Zurich, University of Zurich, Department of Rheumatology, Center of Experimental Rheumatology, Zurich, Switzerland

Background: Fos-like 2 (Fosl-2) is a transcription factor of the AP-1 family and has a broad range in inducing cellular changes affecting fibrosis and inflammatory responses. Pathological effects of Fosl-2 have been associated with systemic sclerosis (SSc). In addition, increased expression of Fosl-2 has been detected in human SSc monocyte-derived macrophages [1]. Monocytes and macrophages play a central role in activating and propagating acute inflammation followed by pathological fibrosis and organ dysfunction. The classification of the macrophage polarization phenotype can be assigned based on the stimulus, for example into classically-activated M(LPS), and alternatively-activated M(IL-4) macrophages [2]. However, the role of the Fosl-2 transcription factor in macrophage polarization remains elusive. Objectives: To investigate the role of Fosl-2 in macrophage polarization in SSc using Fosl-2 overexpressing transgenic (Fosl-2 tg) mice and human blood-derived macrophages from SSc patients.

Methods: Thiogylcolate-elicited peritoneal macrophages were isolated from wildtype (wt) and Fosl-2 tg mice. Human peripheral CD14 ${ }^{+}$blood-derived monocytes were isolated and differentiated to macrophages (hMDM) from healthy controls and SSc patients. Murine and human macrophages were polarized with LPS $(10 \mathrm{ng} / \mathrm{ml})$, LPS + recombinant mouse IFN- $\gamma(10 \mathrm{ng} / \mathrm{ml})$, recombinant mouse, resp. human IL-4 $(10 \mathrm{ng} / \mathrm{ml})$ or remained untreated. Macrophage surface marker expression was assessed by flow cytometry using a mouse (F4/80, CD11b, CD86, CD80, CD38, MHCII, CD206, PD-L1, PD-L2, CD36) or human (CD38, CD40, CD86, PD-L2, PD-L1, CD163, CD206) designed polarization panel. Phagocytic activity was detected with pHrodo Red E.coli particles by flow cytometry. Gene expression and secretion of pro- and anti-inflammatory markers were measured by RT-qPCR, standard ELISAs and Griess Assay for nitric oxide production.

Results: After LPS stimulation, mRNA levels of IL-1 $\beta(p<0.01, n=11-12)$, TNF- $\alpha$ $(p=0.05, n=11-12)$ and IFN- $\gamma(p<0.05, n=7)$ were reduced, whereas expression of IL-10 $(p<0.05, n=11-12)$ was enhanced in Fosl-2 tg peritoneal macrophages in comparison to wt cells. Secretion of TNF- $\alpha(p<0.01, n=9-11)$ and nitric oxide $(p<0.01, n=9)$ was impaired in Fosl-2 tg peritoneal macrophages compared to wt cells after LPS stimulation. Peritoneal macrophages were analyzed directly after isolation for macrophage polarization cell surface marker expression. Fosl-2 tg peritoneal macrophages showed an increase in the F4/80 ${ }^{+} \mathrm{CD} 11 \mathrm{~b}^{+} \mathrm{PD}-\mathrm{L}_{2}{ }^{+} \mathrm{CD} 36^{+}$ cell population ( $p<0.01, n=3-6$ ) compared to peritoneal macrophages from wt mice. The expression of cell surface markers of non-polarized and IL-4 stimulated SSc hMDM $(n=17)$ showed an increased percentage of $C D 40^{+} C D 86^{+} C D 206^{+} P D-$ $\mathrm{L}^{+} \mathrm{CD}_{163^{+}}$cells $(\mathrm{p}<0.05)$ compared to healthy control hMDM $(\mathrm{n}=7)$. Phagocytic activity was enhanced in SSc hMDM $(n=7)$ compared to healthy untreated $(p<0.05)$, LPS $(p=0.05)$ and IL-4 $(p<0.05)$ hMDM $(n=5)$.

Conclusion: Our animal data indicates a role of Fosl-2 in regulating macrophage polarization with a shift from a classically-activated to an alternatively-activated phenotype. Similarly, SSc hMDM resemble a functional M(IL-4) alternative macrophage phenotype. Thus, maintaining a balanced proportion of classically- and alternatively-activated macrophage phenotypes may be an effective tool to control macrophage function in SSc.

\section{REFERENCES:}

[1] Moreno-Moral, A., et al., Changes in macrophage transcriptome associate with systemic sclerosis and mediate GSDMA contribution to disease risk. Ann Rheum Dis, 2018. 77(4): p. 596-601.

[2] Kania, G., M. Rudnik, and O. Distler, Involvement of the myeloid cell compartment in fibrogenesis and systemic sclerosis. Nat Rev Rheumatol, 2019. 15(5): p. 288-302.

Disclosure of Interests: Amela Hukara: None declared, Michal Rudnik: None declared, Chantal Brigitta Rufer: None declared, Oliver Distler Speakers bureau: Actelion, Bayer, Boehringer Ingelheim, Medscape, Novartis, Roche, Menarini, Mepha, MSD, iQone, Pfizer, Consultant of: Abbvie, Actelion, Acceleron Pharma, Amgen, AnaMar, Arxx Therapeutics, Bayer, Baecon Discovery, Blade Therapeutics, Boehringer, CSL Behring, ChemomAb, Corpuspharma, Curzion Pharmaceuticals, Ergonex, Galapagos NV, GSK, Glenmark Pharmaceuticals, Inventiva, Italfarmaco, iQvia, Kymera, Medac, Medscape, Mitsubishi Tanabe Pharma, MSD, Roche, Sanofi, UCB, Lilly, Target BioScience, Pfizer, Grant/research support from: Actelion, Bayer, Boehringer Ingelheim, Kymera Therapeutics, Mitsubishi Tanabe, Przemyslaw Blyszczuk: None declared, Gabriela Kania: None declared DOI: 10.1136/annrheumdis-2021-eular.3124

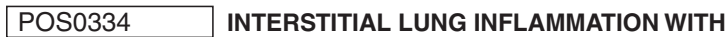 ALVEOLAR HEMORRHAGE IN AUTOIMMUNE MRL/ MP-LPR/LPR MICE}

S. Sato ${ }^{1} .{ }^{1}$ Saitama Children's Medical Center, Division of Infectious Diseases and Immunology and Allergy, Saitama, Japan

Background: Anti-melanoma differentiation-associated gene 5 (MDA5) antibody is associated with interstitial lung disease (ILD) in patients with juvenile dermatomyositis (JDM). Although the mechanisms leading to pulmonary involvements remain uncertain, both inflammatory cytokines and autoimmune response between MDA5 and anti-MDA5 antibody could been inferred. The present study examined the roles of MDA5 in an inducible form of lung involvement that develops in autoimmune mice treated with the pristane.

Objectives: MRL/Mp-lpr/lpr mice and wild type controls $(+/+)$ at 5 weeks of age. They received $0.5 \mathrm{ml}$ of pristane or an equal volume of PBS IP at the age 7 week (day 1). And $1.2 \mu \mathrm{g}$ of recombinant human MDA5 protein (rMDA5) was instilled IP or PBS at day2 and Day9. The mice were sacrificed on 8 weeks after the intraperitoneal injection. Lung tissue was harvested for histological assessment Methods: MRL/Mp-Ipr/Ipr mice and wild type controls $(+/+)$ at 5 weeks of age. They received $0.5 \mathrm{ml}$ of pristane or an equal volume of PBS IP at the age 7 week (day 1). And $1.2 \mu \mathrm{g}$ of recombinant human MDA5 protein (rMDA5) was instilled IP or PBS at day2 and Day9. The mice were sacrificed on 8 weeks after the intraperitoneal injection. Lung tissue was harvested for histological assessment. Results: Lung involvements did not develop in PBS-treated MRL/lpr mice and WT mice. And Lung involvements did not develop in rMDA5 protein-treated WT mice. H\&E staining of lung tissue from MRL/Ipr mice and WT mouse with pristane that showed induced bland alveolar hemorrhage. H\&E staining of lung from WT mouse compared with lung from a MRL/lpr mouse treated with pristane + rMDA5 protein showing mild thickening of the alveolar septa despite the alveolar hemorrhage. And perivascular lymphocytes infiltrate in a MRL//pr mouse rather than a WT mouse treated with pristane + rMDA5 protein. CD163 staining of alveolar macrophages were present in the alveolar spaces was more intense in mouse treated with pristane + rMDA5 protein than in mouuse treated with only pristane. The Lymphocyte infiltrations around alveolar macrophages was more prominent in MRL/Ipr mouse treated with pristane + rMDA5 protein than other mouse.

Conclusion: These results suggest that lung involvements such as the alveolar hemorrhage, are caused by pristeine and rMDA5 prtotein in the pathogenesis of interstitial pneumonia. MRL/Ipr mouse treated with pristane + rMDA5 protein showed more alveolar macrophages that had lymphocyte infiltrations. After the alveolar hemorrhage by pritane, the antigen exposure of MDA5 might induce continuously inflammatory response to lymphocytes and macrophages in the alveolar lesions.

\section{REFERENCES:}

[1] Sunderrajan VE, McKenzie NW, Lieske RT, et al. Pulmonary inflammation in autoimmune MRL/Mp-lpr/lpr mice. Histopathology and bronchoalveolar lavage evaluation. Am J Pathol. 1986;124: 353-362.

[2] Tolga Barker T, Lee YP, Scumpia KK, et al. Pathogenic role of B-cells in the development of diffuse alveolar hemorrhage induced by pristane. Lab Invest 2011; 91: 1540-1550.

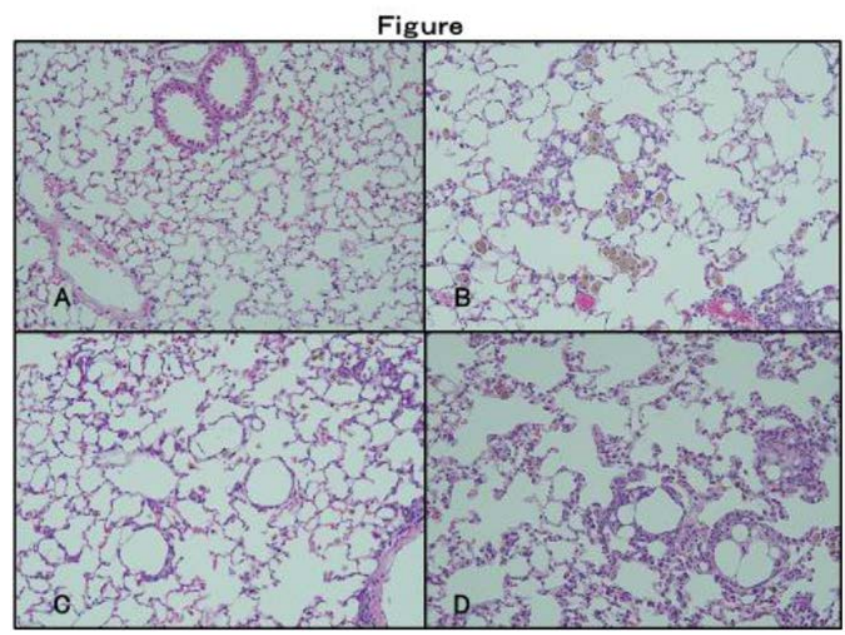

Figure 1. Lung disease (A-D).Light microscopy. Lung tissue from mice 8 weeks after treatment were stained with H\&E. (A) Pristeine -treated WT mice with almost no alveolar lesions. (B) Pristane + rMDA5 protein -treated WT mice with alveolar hemorrhage and slight lymphocyte infiltrations. (C) Pristeine -treated MRL/lpr mouse with almost no alveolar lesions and sligh lymphocyte infiltrations. (D) Pristeine -treated MRL/lpr mouse with alveolar hemorrhage and lymphocyte infiltrations, thickening of the alveolar septa.

Disclosure of Interests: None declared DOI: 10.1136/annrheumdis-2021-eular.3411 